\title{
INFLUENCES OF SHOPPING LIFESTYLE AND REFERENCE GROUPS TOWARDS PURCHASE INTENTION OF PRELOVED FASHION
}

\author{
Isma Nurhikmah Apupianti*1, Ujang Sumarwan ${ }^{* *}$, and Netti Tinaprilla ${ }^{* * *}$ \\ *) School of Business, IPB University \\ Jl. Raya Pajajaran, Bogor 16151 \\ ${ }^{* *}$ Department of Family and Consumer Sciences, Faculty of Human Ecology, IPB University \\ Jl. Lingkar Akademik, Kampus IPB Dramaga, Bogor 16680 \\ ${ }^{* * *}$ Department of Agribusiness, Faculty of Economics and Management, IPB University \\ Jl. Agatis, Kampus IPB Dramaga, Bogor 16680
}

\begin{abstract}
This research aims to analyze the influence of reference groups on shopping lifestyle and also the influence of shopping lifestyle and reference groups towards online preloved fashion's purchase intention. This research is based on the theory of factors that influence consumer behavior developed by Engel et al. (1994). In addition, shopping lifestyle is based on the theory developed by Seock (2003) and reference groups developed by Schiffman and Kanuk (2007) and Sumarwan (2011). The design of this research was a cross-sectional study with survey method answered by online open-close ended questionnaire and interview. This research involved 201 samples which were selected by using convenience sampling. There are two endogen latent variables in this research include shopping lifestyle (shopping enjoyment, brand consciousness, price consciousness, shopping confidence, in-home shopping tendency, quality and environmental consciousness) and reference groups. Whereas exogen latent variable is purchase intention. The data obtained were processed using Structural Equation Model (SEM) method through SmartPLS 3.0. Shopping lifestyle has a significant and positive influence towards purchase intention. The highest contribution derived from shopping confidence and the lowest contribution derived from environmental consciousness. Reference groups ha a significant and positive influence on shopping lifestyle. But, reference groups ha no influence on purchase intention because it could not give the strong effects both in using and buying process.
\end{abstract}

Keywords: online preloved fashion, purchase intention, reference groups, shopping lifestyle

\begin{abstract}
Abstrak: Penelitian ini bertujuan menganalisis pengaruh kelompok acuan terhadap gaya hidup berbelanja serta pengaruh gaya hidup berbelanja dan kelompok acuan terhadap minat beli produk fashion preloved online. Penelitian ini berdasarkan pada teori faktor yang memengaruhi perilaku konsumen yang dikembangkan oleh Engel et al. (1994). Selain itu, variabel gaya hidup berbelanja berdasarkan pada teori yang dikembangkan oleh Seock (2003) dan variabel kelompok acuan berdasarkan pada teori yang dikembangkan oleh Schiffman dan Kanuk (2007) serta Sumarwan (2011). Desain penelitian yang digunakan adalah cross sectional design dengan metode survey yang dijawab melalui online open-close ended questionnaire dan wawancara. Penelitian ini terdiri dari 201 responden yang sesuai dengan kriteria yang diambil menggunakan teknik pengambilan contoh convenience sampling. Variabel laten eksogen terdiri dari gaya hidup berbelanja (shopping enjoyment, brand consciousness, price consciousness, shopping confidence, in-home shopping tendency, quality dan environmental consciousness) dan kelompok acuan serta variabel laten endogen yaitu minat beli. Data yang terkumpul dianalisis menggunakan Structural Equation Model (SEM) melalui software SmartPLS 3.0. Gaya hidup berbelanja memiliki pengaruh yang signifikan terhadap minat beli. Kontribusi tertinggi berasal dari shopping confidence sedangkan kontribusi terendah berasal dari environmental consciousness. Kelompok acuan berpengaruh pada gaya hidup berbelanja, tetapi kelompok acuan tidak berpengaruh terhadap minat beli karena pemakaian dan pembelian produk tersebut tidak memberikan dampak kuat pada konsumen sehingga sumber referensi tidak dibutuhkan.
\end{abstract}

Kata kunci: fashion preloved online, gaya hidup berbelanja, kelompok acuan, minat beli

${ }^{1}$ Corresponding author:

Email:ismanurhikmahapupianti@gmail.com 


\section{INTRODUCTION}

The emergence and rapid development of the internet in Indonesia allowed marketers to offer products or services larger than before. The growth of Indonesian internet users reaches 143.26 million people which were $54.68 \%$ of the population in early 2017 (APJII, 2017). One of many uses of the internet was for online shopping. According to Zhu et al. (2011) and Ula (2018), there were several factors that encouraged online shoppings such as the perception of the easy usage, as well as the perceptions of the function, trust and adjustability of the system for the shopping lifestyle.

Indonesia Market Research Association stated that fashion products had one of the highest percentages in online shopping and would be estimated to affect consumers' purchase decisions in the following year (PERPI, 2017). The sales and purschases of online fashion products not only included new products but also preloved fashion products. Preloved is product which were previously owned and used but still maintained a good condition, despite not being the same as the new product (Roux and Guiot, 2008). Out of many researches regarding preloved fashion products, some still focused on the effect of consumption value (Kim and Kim, 2013; Park and Choo, 2013), and the products' attributes (Bashir et al. 2016) towards purchase intention.

Meanwhile, marketers had to obtain information regarding the perception of consumer intention. It was predicted that the consumers of preloved fashion products would increase up to $70 \%$ in the next year (thredUp, 2018), igniting a competition between marketers to attract more consumers. This business opportunity was growing and its market value would be predicted to rise up gradually. The Indonesian government also had a regulation regarding the supply of used clothes in Undang-Undang Nomor 7 Tahun 2014 Tentang Perdagangan (Kemendag, 2015). These was another obstacle for increasing the consumer intention on purchasing online preloved fashion products.

Marketers of preloved fashion could use the society's lifestyle changing and its social influences to understand the consumers behavior, especially on the purchase intention. Syahmedi Dean and Bagus Takwin stated that the middle-class society in big cities had the need to fulfil the current fashion trend and lifestyle in a realistic manner (Azizah, 2016). Bagus Takwin also stated that the reference groups has the influence of preloved's trend in Indonesia (Azizah, 2016). The shopping lifestyle is part of individual factors, while reference groups is part of external factors that could affect the changes of consumers behavior (Engel et al. 1994; Kotler and Keller, 2003).

Researches on the consumers behavior towards online preloved fashion products were rarely done in Indonesia. A research by Mubarak dan Sanawiri (2018) analyzed the effects of the fashion lifestyle towards the buying decision of used clothes, but it only focused on one particular online shop@Tangankedua. Furthermore, another previous study about shopping lifestyle and reference groups had not covered preloved fashion whereas it is a developing business in Indonesia.

Lifestyle was a reflection of consumer behaviors on spending his/her life, using his/her money, and implementing his/her time well (Engel et al. 1994; Mowen and Minor, 1998). Consumers had their own preferences when they went shopping, which reflected their lifestyle. According to Mokhlis (2006), shopping orientation was one of the concepts of consumer behaviors that could classify a consumer based on behaviors and shopping lifestyle. The understanding of this lifestyle would assist marketers on promoting and communicating the products effectively (Preez et al. 2007).

Seock (2003) and Seock and Bailey (2008) classified the orientation of online shopping into seven dimensions such as shopping enjoyment, brand/ fashion consciousness, price consciousness, shopping confidence, convenience/time consciousness, in-home shopping tendency, and brand/store loyalty. Meanwhile, Ling et al. (2010) and Kaur (2018) added the quality consciousness to measure shopping orientation. The previous studies showed that shopping orientation has a positive and significant influence towards purchase intention on clothing products (Kusuma and Septarini, 2013; Yan et al. 2015; Loureiro and Breazeale, 2016; Kaur, 2018). In addition, Thamizhavanan and Xavier (2013) and Ghouri et al. (2017) concluded that shopping orientation has a significant influence on online purchase intention. 
Reference groups referred to an individual or a group who realistically affected the purchase decision (Schiffman and Kanuk, 2007). It was a source of reference and an opinion leader for consumers in deciding what to buy. Opinions by a reference groups could be the base of a consumer's lifestyle. Solomon and Englis (2013) stated that the group affect the consumer's decision to adopt or decline the product, service, or a particular activity. Furthermore, Fernandes and Tovinakere (2018) concluded that the change of a consumer's lifestyle was affected by a social groups.

Another studies about reference groups showed that such groups like families, friends, and idols influenced the purchase decisions in the Crezh Republic (Turcinkova and Moisidis, 2011). Reference groups could also have a great influence on individuals, in particular the consumption behaviors of women (Fernandes and Panda, 2015). In addition, Tuu et al. (2010) and Sangkakoon et al. (2014) concluded that reference groups also influenced the purchase intention.

The purpose of the research is to analyze the influences of reference groups towards shopping lifestyle, as well as the influences of the shopping lifestyle and reference groups towards purchase intention of online preloved fashion's products. The scope of this research focused on 18-44 years old consumers of branded preloved fashion who ever purchase this product at least once in the last twelve months through e-commerce or s-commerce.

Therefore, it can be formed research hypothesis as follow: (1) there is a significant and positive influence of reference groups towards shopping lifestyles, (2) there is a significant and positive influence of reference groups towards purchase intention, and (3) there is a significant and positive influence of shopping lifestyle towards purchase intention of online preloved fashion's products.

\section{METHODS}

The research was conducted on the consumers of online preloved fashion's products from October to November 2018. A cross-sectional survey design used as research design which includes primary and secondary data. Primary data collected through online open-close questionnaire and in-depth interview, while secondary data collected through literature. The approach of this study used a quantitative descriptive method.
The research acquired samples by following the concept of Hair et al. (2006), which was every estimated parameter of exogenous and endogenous variables was around five to ten observations, and the recommended amount was around 150-300 people. There were 354 respondents, but only 201 that fulfilled the criteria. The sampling was acquired through the convenience sampling technique, which was based on the availability and easiness of the sampling (Sumawarman, 2011). The technique began by sharing the questionnaire link into Whatsapp and Line accounts of families, friends, and co-workers. Then, the same link would be shared through direct message in social media and mobile application. Furthermore, 23 respondents were interviewed in order to obtain additional information regarding the consumption behaviors of online preloved fashion's products.

The exogenous latent variables were consisted of the shopping lifestyle and reference groups, while the endogenous latent variable was the purchase intention. The variable of lifestyle consisted of twenty three indicators, three for reference groups, and four for the purchase intention. The research implemented interval scales consisted of five categories (1) totally disagree, (2) disagree, (3) neutral, (4) agree, (5) totally agree. The definitions of variables and indicators could be seen in Table 1.

The data were analyzed using the Structural Equation Model (SEM) PLS to discover the effects of the variables. SEM was implemented for the analysis because it could analyze the relation or influence between latent and indicator variables directly (Latan and Ghozali, 2012; Puspitawati, 2013). The conceptual framework could be seen in Figure 1.

Reference groups, which provided opinions to an individual on purchasing the products, allegedly influenced the shopping lifestyle and purchase intention. Solomon and Englis (2013) stated that the groups had a connection on how an individual consume the product. In addition, Schiffman and Kanuk (2007) stated that reference groups affected the purchase decision. Based on those statements, there is an influence of reference groups towards shopping lifestyle (H1) and there is an influence of reference groups towards purchase intention (H2). 
Table 1. Operational definitions of variables and indicators

\begin{tabular}{|c|c|c|c|}
\hline Latent variable & Operational definitions & Code & Sources \\
\hline \multicolumn{4}{|c|}{ Shopping Lifestyle (GHB) } \\
\hline Shopping Enjoyment & $\begin{array}{l}\text { A tendency of consumers to enjoy shopping } \\
\text { online preloved fashion }\end{array}$ & SE1-SE3 & \multirow{3}{*}{$\begin{array}{l}\text { Mokhlis (2006); Seock and } \\
\text { Bailey, (2008); Nirmala } \\
\text { and Dewi, (2011) }\end{array}$} \\
\hline $\begin{array}{l}\text { Brand/Fashion } \\
\text { Consciousness }\end{array}$ & $\begin{array}{l}\text { A tendency of consumers to be oriented on brand } \\
\text { name or fashion trend }\end{array}$ & $\mathrm{BC} 1-\mathrm{BC} 4$ & \\
\hline Price Consciousness & A tendency of consumers to be oriented on price & PC1-PC3 & \\
\hline Shopping Confidence & $\begin{array}{l}\text { A tendency of consumers to be confident when } \\
\text { shopping online preloved fashion }\end{array}$ & $\mathrm{SC} 1-\mathrm{SC} 3$ & \multirow[t]{2}{*}{$\begin{array}{l}\text { Seock and Bailey, (2008); } \\
\text { Nirmala and Dewi (2011) }\end{array}$} \\
\hline $\begin{array}{l}\text { In-home Shopping } \\
\text { Tendency }\end{array}$ & $\begin{array}{l}\text { A tendency of consumers to shop preloved } \\
\text { fashion from home }\end{array}$ & ST1-ST3 & \\
\hline Quality Consciousness & $\begin{array}{l}\text { A tendency of consumers to be oriented on } \\
\text { preloved fashion's quality }\end{array}$ & QC1-QC4 & $\begin{array}{l}\text { Mokhlis (2006); Ling et } \\
\text { al. (2010); Edward and } \\
\text { Eriksson (2014) }\end{array}$ \\
\hline $\begin{array}{l}\text { Environmental } \\
\text { Consciousness }\end{array}$ & $\begin{array}{l}\text { A tendency of consumers to be oriented on } \\
\text { environmental issues }\end{array}$ & EC1-EC3 & $\begin{array}{l}\text { Edward dan Eriksson } \\
\text { (2014); Yan et al. (2015) }\end{array}$ \\
\hline Reference Groups & $\begin{array}{l}\text { Consumers perception towards the influence } \\
\text { of opinion leader on online preloved fashion's } \\
\text { purchase intention }\end{array}$ & KA1-KA3 & $\begin{array}{l}\text { Edward and Eriksson } \\
\text { (2014) }\end{array}$ \\
\hline Purchase Intention & $\begin{array}{l}\text { Consumers' intention to purchase preloved } \\
\text { fashion }\end{array}$ & MB1-MB4 & $\begin{array}{l}\text { Maichun et al. (2016); Hsu } \\
\text { et al. (2017) }\end{array}$ \\
\hline
\end{tabular}

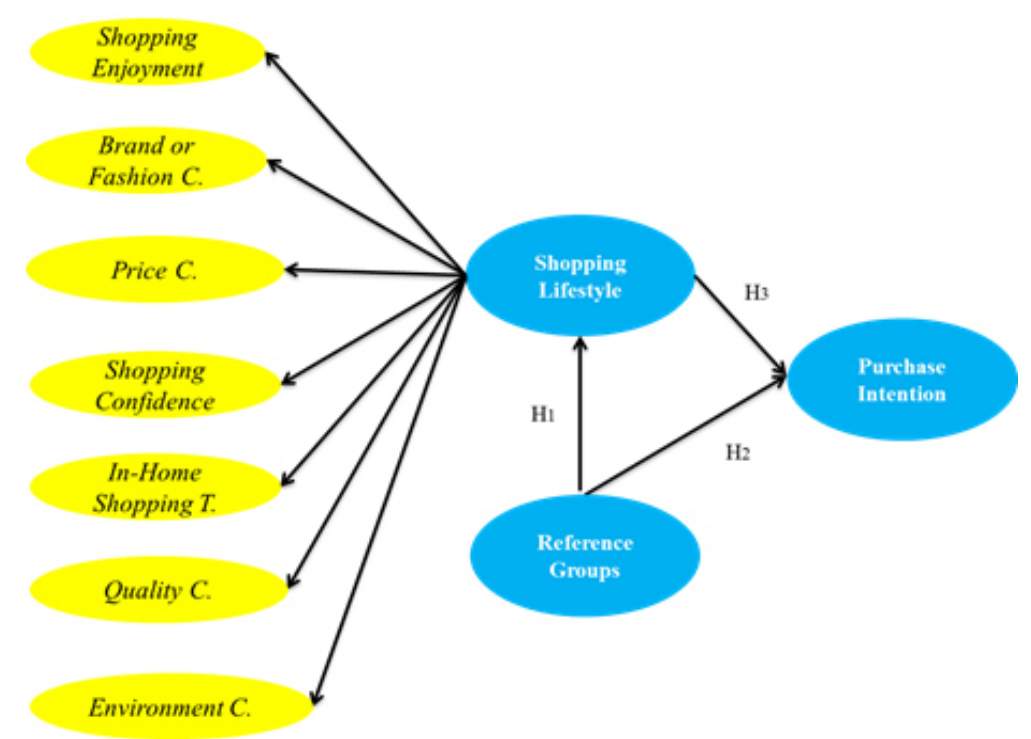

Figure 1. Conceptual framework

Lifestyle of the society when purchasing fashion items had been changed. Consumers had their own orientation when purchasing fashion products such as shopping enjoyment, brand consciousness, price consciousness, shopping confidence, and in-home shopping tendency (Seock, 2003), as well as quality consciousness (Mokhlis, 2006) and environmentalism (Yan et al. 2015). These orientations provided opportunities for consumers to shop based on their needs and desire. It can be formed research hypothesis that there is an influence of shopping lifestyle towards purchase intention (H3).

\section{RESULTS}

There was an almost equal amount of male and female respondents, with male at $47 \%$ and female at $53 \%$ within the majority age group of $18-24$ years old $(69 \%)$. Most respondents lived in Jabodetabek area (52.7\%), with the majority of highschool graduates $(35.4 \%)$ ) and bachelor degree graduates (49.2\%). Those respondents dominated by students (38.4\%) and private employees (27.6\%) who have average income per month less than two million rupiah (39\%) and around two to five million rupiah $(33.4 \%)$. 
The dominant product categories chosen by the consumers of preloved fashion were branded products $(60 \%)$ and vintage products $(31 \%)$, with shirts as the commonly chosen products (51\%). The majority of consumers had purchased the product once per six months $(28 \%)$ and once a month $(23 \%)$, respectively. The average spending for preloved fashion products was less five hundred thousand rupiah per purchase $(60 \%)$ and from five hundred thousands to one million rupiah (22\%). There were several reasons why consumers purchased preloved fashion products, such as the products were still in good conditions and had affordable prices. Meanwhile, the main reasons why they chose to purchase online were it saved time, energy, and money, as well as its flexibility. There were several considerations when purchasing the products like quality, originality and affordability.
According to Latan and Ghozali (2008), PLS could predict and test the predictive relationship between constructs, as well as between constructs and the indicators. The evaluation of the PLS model was conducted by evaluating the model of measurement (outer model) and structure (inner model). The result of measurement evaluation shows that all indicators already valid because the value of loading factors was $>0.6$ and AVE value was $>0.5$, indicating that more than $50 \%$ of the variance in the observed variable was explained by the indicators. Moreover, all indicators already reliable because it fulfilled rule of thumb of Cronbach's alpha $>0.6$ and composite reliability $>0.7$. The result could be furtherly seen in Table 2 .

Table 2. Measurement evaluation result

\begin{tabular}{|c|c|c|c|c|c|}
\hline Variable & Indicator & Code & Loading Factor & Validation & AVE \\
\hline \multirow{23}{*}{$\begin{array}{l}\text { Shopping } \\
\text { Lifestyle }\end{array}$} & \multirow[t]{3}{*}{ Shopping Enjoyment (SE) } & SE1 & 0.81 & Valid & 0.61 \\
\hline & & SE2 & 0.82 & Valid & \\
\hline & & SE3 & 0.71 & Valid & \\
\hline & \multirow{4}{*}{$\begin{array}{l}\text { Brand/Fashion } \\
\text { Consciousness (BC) }\end{array}$} & $\mathrm{BC} 1$ & 0.73 & Valid & 0.58 \\
\hline & & $\mathrm{BC} 2$ & 0.72 & Valid & \\
\hline & & $\mathrm{BC} 3$ & 0.82 & Valid & \\
\hline & & $\mathrm{BC} 4$ & 0.78 & Valid & \\
\hline & \multirow[t]{3}{*}{ Price Consciousness (PC) } & PC1 & 0.67 & Valid & 0.60 \\
\hline & & PC2 & 0.84 & Valid & \\
\hline & & PC3 & 0.81 & Valid & \\
\hline & \multirow[t]{3}{*}{ Shopping Confidence (SC) } & $\mathrm{SC} 1$ & 0.84 & Valid & 0.75 \\
\hline & & $\mathrm{SC} 2$ & 0.91 & Valid & \\
\hline & & $\mathrm{SC} 3$ & 0.84 & Valid & \\
\hline & \multirow{3}{*}{$\begin{array}{l}\text { In-Home } \\
\text { Shopping Tendency (ST) }\end{array}$} & ST1 & 0.83 & Valid & 0.61 \\
\hline & & ST2 & 0.86 & Valid & \\
\hline & & ST3 & 0.64 & Valid & \\
\hline & \multirow[t]{4}{*}{ Quality Consciousness (QC) } & QC1 & 0.83 & Valid & 0.61 \\
\hline & & QC2 & 0.78 & Valid & \\
\hline & & QC3 & 0.76 & Valid & \\
\hline & & QC4 & 0.75 & Valid & \\
\hline & \multirow{3}{*}{$\begin{array}{l}\text { Environmental Consciousness } \\
\text { (EC) }\end{array}$} & EC1 & 0.91 & Valid & 0.81 \\
\hline & & $\mathrm{EC} 2$ & 0.92 & Valid & \\
\hline & & EC3 & 0.87 & Valid & \\
\hline \multirow{3}{*}{$\begin{array}{l}\text { Reference } \\
\text { Groups (KA) }\end{array}$} & & KA1 & 0.88 & Valid & 0.67 \\
\hline & & KA2 & 0.84 & Valid & \\
\hline & & KA3 & 0.73 & Valid & \\
\hline \multirow{4}{*}{$\begin{array}{l}\text { Purchase } \\
\text { Intention (MB) }\end{array}$} & & MB1 & 0.89 & Valid & 0.70 \\
\hline & & MB2 & 0.86 & Valid & \\
\hline & & MB3 & 0.70 & Valid & \\
\hline & & MB4 & 0.89 & Valid & \\
\hline
\end{tabular}


The parameter used to evaluate the structural evaluation was coefficiency determinant (R2). The R2 rate for the purchase intention of preloved fashion products was 0.57 , indicating that $57 \%$ of variance of purchase intention was explained by shopping lifestyle and reference groups, while the remaining $43 \%$ explained by other variables that were not included in the research model. Meanwhile, the evaluation of the overall goodness of fit (GoF) could be conducted through the GoF criteria developed by Tenenhaus et al. (2004) known as the GoF index (Latan dan Ghozali 2008). Based on the evaluation, the rate of GoF index for the research model was around 0.59 . This rate has fit the rule of thumb which should be more than 0.35 so that model can have strong prediction power (Latan dan Ghozali, 2012). The model could be seen in Figure 2.

The evaluation of hypothesis was conducted by testing the path coefficient on the structural model. Path coefficient showed the significant rate of hypothesis evaluation. The hypothesis used for this research was a one-tiled hypothesis with the t-statistics rate more than 1.64. The result could furtherly be seen in Table 3 .

In Table 3, the influence of reference groups towards the shopping lifestyle and the shopping lifestyle towards the purchase intention had a t-value of 3.53 and 21.80 which larger than 1.64, therefore the Hypothesis 1 and Hypothesis 3 were accepted. Compared to Hypotheses 1 and 3 , the influence of reference groups towards the purchase intention had a t-value of 0.31 which smaller than 1.64, making the Hypothesis 2 was rejected. Besides the direct effect, the research also tested the indirect effect on the reference groups (KA) towards the purchase intention (MB) through the shopping lifestyle (GHB). The result of the indirect effect had a $\mathrm{t}$-value of 3.44 which larger than 1.64.

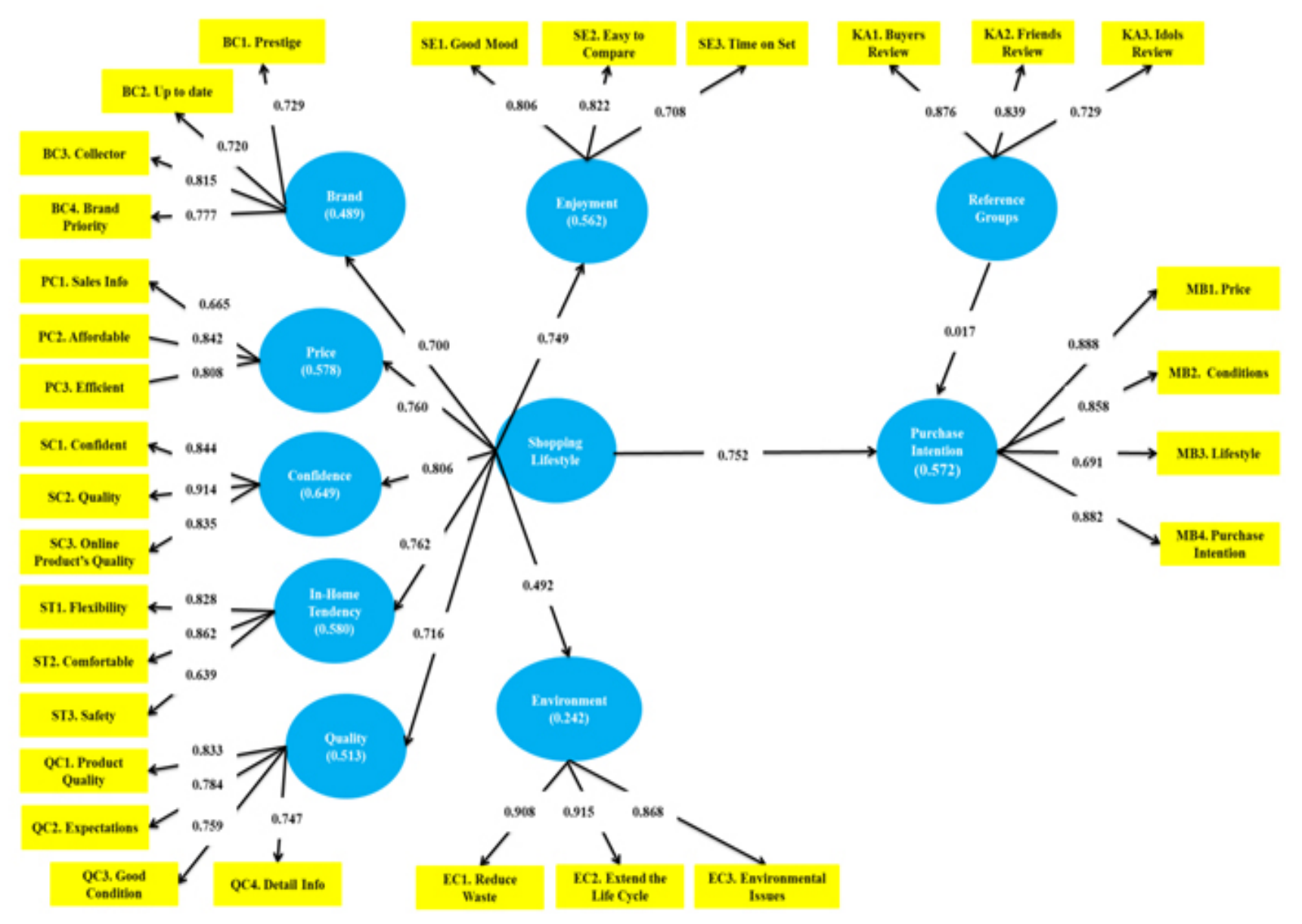

Figure 2. Model's path diagram 
Table 3. Structural evaluation result

\begin{tabular}{lccc}
\hline & Path Coefficient & t-value & Test Result \\
\hline $\mathrm{KA} \rightarrow \mathrm{GHB}$ & 0.26 & 3.53 & Significant \\
$\mathrm{KA} \rightarrow \mathrm{MB}$ & 0.02 & 0.31 & Not Significant \\
$\mathrm{GHB} \rightarrow \mathrm{MB}$ & 0.75 & 21.80 & Significant \\
\hline
\end{tabular}

Hypothesis 1. Reference groups has a positive and significant influence towards shopping lifestyle. The groups had three indicators, the influence of information from other buyers (KA1), friends/coworkers (KA2), and idols (KA3). These three groups became the sources of reference for an individual to conduct an activity, use the money and spend the time. This result has supported by Choudhary et al. (2013), Limbad (2013), and Fernandes and Londhe (2015). They concluded that social groups influenced the consumers behaviors and shopping patterns on purchasing a product. A different individual also had a different reference group, as Holtzman (1979) stated that individuals with different reference groups influences would have different lifestyle. For example, a housewife would have a dependency to her husband, while a career woman depended on her co-workers and herself (Holtzman, 1979; Fernandes dan Londhe, 2015).

Hypothesis 2. Reference groups has no influence towards purchase intention. This result did not coincide with Tuu et al. (2010), Moisidis and Turcinkova (2011), and Edward and Eriksson (2014), which stated that there was a positive and significant influence of reference groups towards clothes purchase intention. However, it was supported by Hartatin and Simanjuntak (2016) and Ramadhan (2017). Hartatin and Simanjuntak (2016) stated that even though reference groups had an important role to influence individuals, it did not always refer on purchasing a particular products. Moreover, different types and usages of products would provide different effectiveness towards the influence of reference groups (Engel et al. 1994; Suroyo, 2012). This situation also caused by the fact that reference groups must first influence the lifestyle in order to influence the purchase intention because its indirect effect had a significant influences.

The highest loading factor of reference groups was KA2 and KA1, showing that opinions by friends/coworkers and other buyers contributed greatly towards the reference groups. Reviews from friends/co- workers and other buyers were considered as valuable information because they were direct and honest reviews. According to interview result, it showed that the purchasing process was adjusted by the buyer's personal taste, even though information from reference groups were intended to limit any alternatives. This would provide a conclusion on whether that person decided to purchase an online preloved fashion product or not.

Hypothesis 3. Shopping lifestyle has a positive and significant influence towards purchase intention. The result was supported by Banyte et al. (2015), Ghouri et al. (2017), and Kaur (2018), which stated that the shopping orientation had a great influence towards the online shopping intention. According to Figure 2, shopping confidence (SC) had the highest loading factor (0.81), meaning that $\mathrm{SC}$ has the highest contribution to explain shopping lifestyle. These consumers are consumers who have a tendency to believe and confident towards their shopping ability. Nirmala and Dewi (2011) state that if the consumers become more assured of their shopping ability and select the right product for themselves, they may be less hesitant to purchase that clothes online. According to the interview result, consumers of online preloved fashion's products were in need of detail informations and fast responses from the marketers to convince them on purchasing the right and best products. Indonesian consumers were categorized as the loping consumers, easily changing from one platform to another and making them difficult to remain loyal and were accustomed to multitasking (Burhanudin dan Fisamawati, 2015).

The dimensions of PC (0.76), ST (0.76), and SE $(0.75)$ were in the second highest rate on contributing to explain the shopping lifestyle. The tendency of consumers to consider the prices could describe their behaviors, which were price-oriented while shopping. Consumers with price consciousness may notice, gather the information, and compare every price offered by marketers (Vijayasarathy and Jones, 2000; Vijayasarathy, 2003; Nirmala and Dewi, 2011). 
Wibowo et al. (2018) stated that the acceptance of new technologies could encourage an individual to use those technology. The existence of digital revolution and advanced business environment triggered consumers to fulfill their demands through a better service (Lee and Kim, 2011). Online platform could provide comfort and flexibility in the online transaction. Furthermore, consumers of preloved products use online shopping to keep the shopping activity secret and think about the hygiene of the products.

On the other hand, consumers who have a tendency to enjoy the shopping activity would gladlyspend moretheir time to browse the products. Based on measurements evaluation, the consumers of online preloved fashion products have the tendency to shopping enjoyment. They required an interesting platform and a wide range of information services option. Besides, consumers expect a good performance of the platform which is fast searching and sorting performances, a wide range of products choices, and neat categorization.

The dimensions of QC (0.72), BC (0.69), and EC (0.50) were in the lowest rate. Consumers' perception towards preloved fashion's quality depend on the consumers ability to search and compare the information and choose the right product in the right platform. Furthermore, several consumers did not consider brands as a priority for purchasing fashion products, as they focused more on the utilitarian function of a product.

Most of the consumers in this research also dominated by high school and bachelor graduate which is not have the steady income. The environmental aspect did not encourage them to purchase preloved fashion. They think more about the personal taste. As stated by Seung-Hee (2010), the environmental factor would become an infleunce if there were individuals with vast knowledge about fashion and the effects of fashion industry towards the environment.

\section{Managerial Implications}

Based on the explanations above, there were several managerial implications that were divided into the marketing mix like product, process, promotion, and physical evidence. For marketers, they must focus on the product discovery, the product presentation, and the consideration of the personal selling promotion. Marketers should provide detail information and interesting appearances of the product. Marketers were also expected to provide exciting shopping experiences, especially on product discovery through searching and sorting processes, product presentation such as organized product categories, chatting services and fast and precise deliveries. This is important because current Indonesian consumers are loping consumers.

Marketers also must provide attention to the reviews of previous buyers, which were presented as a physical evidence. Thi was due to the fact that Indonesian consumers were connected consumers that always remained connected with others while shopping. Even though the environmental consciousness dimension had the lowest contribution, marketers could consider to position themselves as online platform that contributed on the environmental issues in the future, caused by the fact that Indonesians were also environmental friendly consumers.

In addition, marketers could consider the personal selling promotion, since several consumers preferred to interact with products and marketers directly. Marketers occasionally must combine both online and offline sales. Marketers should remember that preloved is a second-hand product so these implication at least can strengthen consumers shopping confidence and provide an interesting experience so that the intention can improve.

\section{CONCLUSIONS AND RECOMMENDATION}

\section{Conclusions}

Reference groups has a positive and significant influence towards the shopping lifestyle, but it did not affect the purchase intention of online preloved fashion products. This was caused by the product that could not give strong effects both in using and buying process. However, reference groups could affect the purchase intention through shopping lifestyle. Shopping lifestyle has a positive and significant influence toward purchase intention. Consumers of online preloved fashion products had to be confident with their shopping abilities, being sensitive towards the prices, and enjoying the online shopping process, encouraging them to focus more on the product information and online services. Marketers must focus on product discovery, product presentation, and personal selling promotion, which assisted them to improve consumers' confidence and providing them with exciting experiences. 


\section{Recommendations}

Future research is expected to compare shopping behaviors in online platform, both e-commerce and s-commerce, to discover the difference of strategies between both platforms. In addition, another topic was expected to compare the categories of branded preloved products, with several additional variables such as prior online purchase experience and impulse buying orientation.

\section{REFERENCES}

[APJII] Asosiasi Penyedia Jasa Internet Indonesia. 2017. Penetrasi dan perilaku pengguna internet Indonesia. http://www.apjii.or.id. [2018 July 26].

Azizah R. 2016. Tren preloved online: ketika barang bekas naik kelas. https://www.femina.co.id/. [internet]. [2018 Mai 30].

Banyte J, Rutelione A, Jaruseviciute A. 2015. Modelling male shoppers behavior in shopping orientation context. Science Direct 213: 694-701. https:// doi.org/10.1016/j.sbspro.2015.11.489.

Bashir R, Lodhi RN, Atif M. 2016. Factor influencing the purchase intention of consumer while purchasing second-hand product in pakistan. Arabian Journal of Business and Management Review S3: 008.

Burhanudin T, Fisamawati. 2015. Konsumen Baru yang Mengubah Gaya Pemasaran. Jakarta: Majalah Marketing.

Choudhary A, Munjal S, Rathore R. 2013. Significance of size and body image in buying behavior of females clothing. International Journal of Retailing and Rural Business Perspective 2(4): 629-637.

Edward L, Eriksson C. 2014. Second-hand clothing online: a study of Swedish consumer purchasing intentions [tesis]. Swedia: Unviersity of Boras, The Swedish School of Textiles.

Engel JF, Blackwell RD, Miniard PW. 1994. Perilaku Konsumen Edisi Keenam Jilid 1. Jakarta: Binarupa Aksara.

Fernandes S, Londhe BR. 2015. Influence of social reference group on buying behavior, a comparative study of working and non working women in Bangalore: A pilot study analysis. Indian Journal of Science and Technology 8: 95-124.https://doi.org/10.17485/ijst/2015/
v8iS6/64720.

Fernandes S, Tovinakere R. 2018. Social reference group influence on women buying behaviour: a review. Journal of Commerce and Management Thought 9 (2a): 273-291. https://doi.org/10.5958/0976478X.2018.00019.8.

Fernandes SF, Panda R. 2015. Social reference group influence on women buying behavior: A review. Journal of Commerce and Management Thought 9(2a): 273-291. https://doi.org/10.5958/0976478X.2018.00019.8.

Ghouri AM, Haq MA, Khan NR. 2017. Customer perception on online purchase intention: the impact of online shopping orientations on online buying intention. The Eurasia Proceedings of Science, Technology, Engineering, \& Mathematics (EPSTEM) 1: 76-82.

Hartatin D, Simanjuntak M. 2016. The effect of value and reference group on young consumer's hedonic buying. Journal of Consumer Science 1 (1): 33-46. https://doi.org/10.29244/jcs.1.1.3346.

Holtzman E. 1979. Today's Consumers Want Kinetic Happiness. Marketing News.

Hsu CL, Chang CY, Yansritakul C. 2017. Exploring purchase intention of green skincare products using theory of planned behavior: testing the moderating effects of country of origin and price sensitivity. Elsevier 34: 145-152. https://doi. org/10.1016/j.jretconser.2016.10.006.

Kaur M. 2018. Shopping orientation towards online purchase intention in online apparel purchase environment. International Journal of Advance Research and Innovation 6 (2): 137-142.

[Kemendag] Kementerian Perdagangan. 2015. Laporan analisis impor pakaian bekas. http://bppp. kemendag.go.id. [2019 March 21].

Kim DH, Kim MS. 2013. Perception and buying motives toward purchase behavior of secondhand clothing products. The Research Journal of the Costume Culture 21 (3): 324-337. https://doi. org/10.29049/rjcc.2013.21.3.324.

Kotler P, Keller KL. 2003. Marketing Management: An Asian Perspective 3rd Ed. Singapore: Prentice Hall.

Kusuma DF, Septarini BG. 2013. Pengaruh orientasi belanja terhadap intensi pembelian produk pakaian secara online pada pengguna online shop. J Psikologi Industri dan Organisasi 2(1): 1-9.

Latan H, Ghozali I. 2012. Partial Least Square: Konsep, 
Teknik dan Aplikasi SmartPLS 2.0. Semarang: Badan Penerbit Universitas Diponegoro.

Lee HH, Kim J. 2011. The impact of shopping orientation on us consumer's retail channel choice behavior toward luxury goods purchases. Journal of Global Fashion Marketing 2(4): 188199. https://doi.org/10.1080/20932685.2011.105 93097.

Limbad S. 2013. A study of women's buying behaviour as regards cosmetics in India. http://docplayer. net/32006254-Study-of-women-s-buyingbehaviour-as-regards-cosmetics-in-surat-regionindia.html. [2019 March 20].

Ling KC, Chai LT, Piew TH. 2010. The effects of shopping orientations, online trust and prior online purchase experience toward customers' online purchase intention. International Business Research 3 (3): 63-76. https://doi.org/10.5539/ ibr.v3n3p63.

Loureiro SMC, Breazeale M. 2016. Pressing the buy button: generation y's online clothing shopping orientation and its impact on purchase. Clothing and Textiles Research Journal 34 (3): 1-16. https://doi.org/10.1177/0887302X16633530.

Maichun K, Parichatnon S, Peng KC. 2016. Application of the extended theory of planned behavior model to investigate purchase intention of green products among thai consumers. MDPI 8: 1-20. https://doi.org/10.3390/su8101077.

Mokhlis S. 2006. The effect of religiosity on shopping orientation: an exploratory in malaysia. Journal American Academy of Business 9(1): 64-74.

Mowen JC, Minor M. 1998. Consumer Behavior 5th $E d$. New Jersey: Prentice Hall.

Nirmala RP, Dewi IJ. 2011. The effects of shopping orientations, consumer innovativeness, purchase experience and gender on intention to shop for fashion products online. Gadjah Mada International Journal of Business 13 (1): 65-83. https://doi.org/10.22146/gamaijb.5495.

Park HH, Choo TG. 2013. Influence of consumer selfconfidence in fashion coordination on attitude and purchase intention toward secondhand fashion goods. Journal of the Korean Society of Clothing and Textiles 14(4): 544-553. https:// doi.org/10.5805/KSCI.2012.14.4.544.

[PERPI] Perhimpunan Riset Pemasaran Indonesia. 2017. Indonesia Market Behavior Outlokk 2018. Jakarta: Majalah Marketing.

Preez RD, Visser EM, Zietsman L. 2007. Lifestyle, shopping orientation, patronage behavior, and shopping mall behavior: a study of South African male apparel consumer. J Management Dynamics 16 (1): 2-19.

Puspitawati H. 2013. Riset Pemasaran dan Konsumen. Bogor: IPB Press.

Ramadhan A. 2017. Pengaruh marketing mix, motivasi, dan kelompok acuan terhadap keputusan pembelian rumah cluster puri hasanah 3 Depok [tesis]. Bogor: IPB.

Roux D, Guiot D. 2008. Measuring secondhand shopping motives, antecedents, and consequences. ANR (Recherche et Application en Marketing) 23 (4): 64-94. https://doi. org/10.1177/205157070802300404.

Sangkakoon P, Ngarmyarn A, Panichpathom S. 2014. The influence of group references in home purchase intention in Thailand. Thailand: Thammasat University.

Schiffman LG, Kanuk LL. 2007. Perilaku Konsumen Ed-7. Jakarta: PT Indeks.

Seock YK. 2003. Analysis of clothing websites for young customer retention based on a model of customer relationship management via internet [disertasi]. Blacksburg: Virginia Polytechnic Institute and State University.

Seock YK, Bailey LR. 2008. The Influence of college students' shopping orientation and gender differences on online information searches and purchase behaviours. International Journal of Consumer Studies 32: 113-121. https://doi. org/10.1111/j.1470-6431.2007.00647.x.

Seung-Hee L. 2010. Consumer' purchasing intentions toward sustainable apparel in US. Journal Fashion Business 14 (3): 146-153.

Sumarwan U. 2011. Perilaku Konsumen: Teori dan Penerapannya dalam Pemasaran. Bogor: IPB Press.

Suroyo MF. 2012. Analisis faktor pengaruh kelompok acuan terhadap brand awareness dan peranannya dalam pemilihan merek susu formula bayi [tesis]. Bogor: IPB.

Thamizhvanan A, Xavier MJ. 2013. Determinants of customers' online purchase intention: an empirical study in India. Journal of Indian Business Research 5 (1): 17-32.

thredUP. 2018. thredUP 2018 resale report. https:// www.thredup.com/. [2018 May 30].

Turcinkova J, Moisidis J. 2011. Impact of reference groups on the teenager's buying process of clothing in the Crezh Republic. ACTA 59(7): 489-496. https://doi.org/10.11118/ 
actaun201159070489.

Tuu HH, Anh NTK, Olsen SO, Vassdal T. 2010. Explaining repurchase intention towards in Vietnam: The extension of the theory of planned behavior. IIFET 2010 Montpellier Proceedings.

Ula RRM. 2018. Faktor yang memengaruhi minat mahasiswa untuk membeli barang secara online [tesis]. Bogor: IPB.

Vijayasarathy LR, Jones JM. 2000. Intentions to shop using internet catalogues: exploring the effects of product types, shopping orientations, and attitudes towards computers. Electronic Markets 10 (1): 29-38. https://doi. org/10.1080/10196780050033953.

Vijayasarathy LR. 2003. Shopping orientations, product types, and internet shopping intentions.
Electronic Market 13:67-79. https://doi.org/10.1 080/1019678032000039903.

Wibowo YH, Wijayanto H, Daryanto HK. 2018. Faktor yang memengaruhi minat penggunaan perpustakaan digital (Studi kasus pada IPB dan UBINUS). Jurnal Aplikasi Manajemen dan Bisnis 4(3): 431-440. https://doi.org/10.17358/ jabm.4.3.431.

Yan RN, Bae SY, Xu H. 2015. Second-hand clothing among college student: the role of psychographic characteristics. Emerald Insight 16(1): 85-98. https://doi.org/10.1108/YC-02-2014-00429.

Zhu DS. Lee ZC, O’Neal GS. 2011. MR.Risk! please trust me: trust antecedents that increase online consumer purchase intention. Journal of Internet Banking and Commerce 16 (3): 1-23. 